ISSN 0258-7122 (Print), 2408-8293 (Online)

Bangladesh J. Agril. Res. 42(4): 681-691, December 2017

\title{
ECONOMIC ANALYSIS OF GINGER CULTIVATION IN SELECTED LOCATIONS OF NEPAL
}

\author{
R. R. POUDEL ${ }^{1}$, P. P. REGMI ${ }^{2}$, R. B. THAPA ${ }^{2}$, Y. D. GC ${ }^{3}$ AND D. B. $\mathrm{KC}^{4}$
}

\begin{abstract}
Although Ginger is the main cash crop for small farmers across the country, the economic condition is not satisfactory which can be attributed to high cost of product and low productivity. The study was conducted in four ginger growing areas of Palpa, Nepal in 2012, focusing on cost factors of various inputs. The study revealed that ginger production was profitable on cash cost basis (BCR 7.22). Seed have major cost share for ginger production $(65.1 \%)$. The estimated coefficients of Cobb-Douglas production function showed that seed, labor and number of years for crop rotation were the significant factors for ginger production. The study concluded that ginger production can be made viable enterprise with increased focus on source seed production and distribution.
\end{abstract}

Keywords: Economic analysis, production factor, and profitability.

\section{Introduction}

Agriculture is the mainstay of Nepalese economy. It is contributing about one third of GDP and creating employment opportunity of approximately $66 \%$ of the population (MOAD, 2014). Among them, major are small farmers. Although the government plan and policies has placed agriculture sector in priorities over the years but agriculture growth is in sluggish motion. It is fully dependent on season. The production and productivity is low. The agriculture perspective plan emphasized agricultural growth through agricultural productivity, crop diversification and commercialization of high value agricultural commodities (APPROSC \& JIMA, 1995) in the past. Now Agriculture Development Strategy 2015-2035 has internalized these policies.

Ginger (Zingiber officinale Roscoe) is an important spice crop in Nepal. It is grown all over the country. Government has given importance for ginger crop as a high value crop. As a result its area is increasing. Climate of hilly areas is more suitable for ginger cultivation though Terai is a good alternative. Nearly $72 \%$ of total production is contributed by the hilly regions, remaining $23 \%$ by Terai and $5 \%$ by mountainous region (MOAD, 2014). Eastern region has high contribution of about $35.5 \%$ in production and followed by western region by $24.4 \%$. Similarly Mid - western and far western region has contribution of $16.6 \%$ and $10.8 \%$ respectively (MOAD, 2014). The area and production of ginger in 2013 was 19376 ha and 235033 ton respectively (FAO, 2015) Table 1. Nepal ranks

\footnotetext{
${ }^{1}$ Ministry of Agricultural Development, Regional Agriculture Training Center, Naktajhij, ${ }^{2}$ Institute of Agriculture and Animal Sciences, Rampur, ${ }^{3}$ Department of Agriculture, Kathmandu, ${ }^{4}$ CIMMYT, Nepal.
} 
third in world ginger production with 11.0 percent of the global share, and eighth in yield (12.13 t/ha) in 2013. The annual expansion of 5.94\% of area contributed to increase of $7.88 \%$ annual production with marginal contribution from growth in yield (1.83\% annually). The high variation of ginger production is due to market, climate and pest problems.

Table 1. Annual area, production and productivity of ginger from 2001 to 2013 in Nepal.

\begin{tabular}{l|c|c|c}
\hline Year & Area (ha) & Production (t) & Productivity (t/ha) \\
\hline 2001 & 8956 & 84366 & 9.56 \\
2002 & 9189 & 87909 & 5.69 \\
2003 & 11830 & 150593 & 12.73 \\
2004 & 11930 & 152704 & 12.80 \\
2005 & 12000 & 154200 & 12.85 \\
2006 & 12994 & 154179 & 11.86 \\
2007 & 13025 & 158905 & 12.20 \\
2008 & 14007 & 161171 & 11.50 \\
2009 & 15838 & 178987 & 11.30 \\
2010 & 18041 & 210790 & 11.68 \\
2011 & 19081 & 213353 & 11.33 \\
2012 & 20256 & 255208 & 12.60 \\
2013 & 19376 & 235033 & 12.13 \\
\hline Mean & 14347.9 & 151338 & 11.4024 \\
\hline CV (\%) & 26.66 & 38.03 & 16.94 \\
\hline GR $(\%)$ & 5.94 & 7.88 & 1.83 \\
\hline Durbin Watson & 1.22 & 1.63 & 1.12 \\
\hline
\end{tabular}

Source: FAO, 2015

Even though Nepal ranks third in world ginger production, there are various reasons for the poor yields which need to be identified for appropriate research findings and policy intervention. This lack of information limits the planners to identify and prioritize programmers and policy decisions. Therefore, the research was done with the following objectives:

i. to evaluate profitability of ginger;

ii. to analyze the production factors of ginger and

iii. to identify the constraints of ginger production in western Nepal.

\section{Methodology}

The study on ginger producing farmer was conducted in four Village Development Committee (VDC) of Palpa Nepal during 2012. The study was conducted in Bhairabsthan, Khanigaun, Mujhung and Siluwa VDCs. The study site was selected on the basis of feasibility, level of commercialization, access 
and remoteness. Structured questionnaire was used for data collection. 60 ginger producer farmers were selected using random sampling method from each four VDCs totaling 240 samples. Data taken were on area, production, input costs, product prices, and constraint on ginger production. Field investigators under the direct supervision of the researcher collected field level cross sectional data.

Collected data were edited, summarized, tabulated, and analyzed to fulfill the objectives of the study with the help of Ms-Excel and IBM-SPSS statistics 20. Profitability of ginger production was examined on the basis of gross return, gross margin, and benefit cost ratio analysis. Purchased cost for ginger production was taken as cash cost and total cost as full cost. In calculating gross margin, and benefit cost ratios, all operating costs were considered as variable cost.

\section{Gross margin}

The gross margin provides simple and quick method of farm business analysis. Gross margin was estimated by taking gross return and the total variable cost incurred.

$$
G M=\left[\left(P_{y} * Y\right)+\left(P_{z} * Z\right)\right]-\sum_{i=1}^{n} P_{x_{i}} * X_{i}
$$

Where

$\mathrm{GM}=$ gross margin,

$\mathrm{P}_{\mathrm{y}}=$ price of main product,

$\mathrm{Y}=$ quantity of main product or output,

$\mathrm{Pz}$ = price of byproduct, and

$\mathrm{Z}$ = quantity of byproduct,

$\mathrm{P}_{\mathrm{Xi}}=$ price of $\mathrm{i}^{\text {th }}$ input

$X_{i}=$ quantity of $i^{\text {th }}$ input

Value of ginger byproduct is nominal in the study area, so it is omitted in calculation.

\section{Benefit-cost ratio}

Benefit-cost ratio is the ratio between the gross return and total cost of any enterprise. In this study, benefit-cost ratio was calculated by using the following formula:

Where,

$$
B / C \text { Ratio }=\frac{G \mathrm{R}}{\mathrm{TC}}
$$

$\mathrm{B} / \mathrm{C}$ Ratio $=$ Benefit-Cost ratio

$\mathrm{GR}=$ gross return (it was obtained by adding income from ginger)

$\mathrm{TC}=$ total cost (it was obtained by adding all the expenditures in production process) 
Estimation of production function analysis: The general form of CobbDouglas type production function was used to determine the contribution of different factors of production. Model used for estimating coefficients of ginger production in the study areas is as given below:

$\mathrm{Yg}=\mathrm{a} \mathrm{S}^{\mathrm{b} 1} \mathrm{M}^{\mathrm{b} 2} \mathrm{~L}^{\mathrm{b} 3} \mathrm{Cr}^{\mathrm{b} 4} \mathrm{Fz}^{\mathrm{b} 5} \mathrm{e}^{\mathrm{u}}$

In log linear form, the above model can be expressed as follows

$\ln Y g=\ln a+b_{1} \ln S+b_{2} \ln M+b_{3} \ln L+b_{4} \ln C r+b_{5} \ln F z$

where,

$\mathrm{Yg}=$ Ginger production (NRs)

$\mathrm{S}=$ Cost of seed (NRs)

$\mathrm{M}=$ Manure cost (NRs)

$\mathrm{L}=$ Labor cost $(\mathrm{NRs})$

$\mathrm{Cr}=\mathrm{Crop}$ rotation $($ No. of $\mathrm{Yrs})$

$\mathrm{Fz}=$ Family size (Number)

$\alpha=$ Coefficient

The intercept has been denoted by ' $a$ ' and ' $b_{i}$ ' are the associated slope coefficient of the variable $X_{i}$, where $i=1 \ldots 5$.

\section{Results and Discussion}

\section{Ginger cultivation practices}

On an average, per farmer, 0.067 hectare of land was devoted to ginger cultivation in the study areas. Most of the inputs like labor, seed and manure were supplied by farmers themselves. Own Labor supply, seed use and manure supply was $83.44 \%, 85 \%$ and $99 \%$ respectively (Table 2). Ginger in Palpa was mostly cultivated intercropped with maize $(99.25 \%)$. As it is moderate shade loving plant, intercropping with maize provide both grain and shed. Similar result was derived by Lyocks et al. (2013). Crop rotation in ginger is very important and year after year the cultivation of ginger in the same land is not recommended (Rahman et al., 2009). In the study areas average years of crop rotation was 2.1 years. Only $2 \%$ farmers used organic pesticide which was observed only in Bhairabsthan. Sowing period lasted from March till May. Within the month of April 78\% farmers completed sowing rhizomes indicated that main season for planting in mid hill was April. Respondent farmers reported different species of tree leaves using as mulching material. The most common three tree species were chestnut (Castonopsis indica), needlewood (Schkima wallichii) and Nepalese alder (Alnus nepalensis). 
Table 2. Ginger cultivation practices of the sample farmers in the study areas.

\begin{tabular}{|c|c|c|c|c|c|}
\hline \multirow{2}{*}{ Particulars } & \multicolumn{4}{|c|}{ Study Area } & \multirow{2}{*}{ All Areas } \\
\hline & Bhairabsthan & Khanigaun & Mujhung & Siluwa & \\
\hline Average ginger areas (ha) & 0.11 & 0.08 & 0.05 & 0.03 & 0.067 \\
\hline Own land use (\%) & 98 & 95 & 100 & 100 & 98.5 \\
\hline Own labor use $(\%)$ & 72.5 & 88.5 & 88.58 & 84.16 & 83.44 \\
\hline Own seed use $(\%)$ & 59.2 & 92.9 & 82.71 & 91.58 & 85 \\
\hline Own Manure use (\%) & 99.3 & 99.3 & 98.75 & 100 & 99 \\
\hline Intercropped with maize $(\%)$ & 98 & 99 & 100 & 100 & 99.25 \\
\hline Crop rotation (Years) & 2.67 & 1.73 & 1.7 & 2.37 & 2.1 \\
\hline Organic pesticide use $(\%)$ & 8 & - & - & - & 2 \\
\hline \multicolumn{6}{|l|}{ Month of Sowing (\%): } \\
\hline March & 6 & 2 & 3 & 10 & 5.25 \\
\hline April & 90 & 75 & 82 & 65 & 78 \\
\hline May & 4 & 23 & 15 & 25 & 16.75 \\
\hline Mulching materials & \multicolumn{5}{|c|}{$\begin{array}{l}\text { Different species tree, mostly Castonopsis indica, Schkima } \\
\text { wallichiin and Alnus nepalensis }\end{array}$} \\
\hline
\end{tabular}

\section{Input use pattern}

The pattern of input use is presented in Table 3. On an average, ginger farmers used 266 man-days of human labor per hectare of which $83.44 \%$ were family supplied. The farmers of Siluwa used the highest number of human labor (442 man-days/hac) compared to average use (225 man-days/ha). It was for more organic manure application and collection of mulching materials from the forest. The t-test for own and hired labor use showed significant difference in all study areas. On an average, $2873 \mathrm{~kg}$ of seed per hectare was used which was higher than the recommended. At the time of harvest farmer get lower price of fresh ginger so, they prefer to sell mother rhizome at higher price as early harvest. Another reason for higher rate of seed is that they use larger size for robust growth. Similar type of findings was found from Monnaf et al. (2010). Farmers used more than $85 \%$ of required seed from their own sources. On an average, farmers used $26275 \mathrm{~kg}$ manures/ha, which was more $(38657 \mathrm{~kg} / \mathrm{ha}$ ) in Siluwa (remote and semi-commercial farming VDC). It was because of the highest livestock unit (LSU) holdings per household (Poudel et al., 2015). The least use of manure was $(16373 \mathrm{~kg} / \mathrm{ha})$ in Bhairabsthan (access and commercial farming VDC). There was no use of chemical fertilizer in the study areas. 
Table 3. Level of input use per hectare for ginger cultivation in the study areas

\begin{tabular}{lcccccc}
\hline \multicolumn{1}{c}{ Type of input } & Bhairabsthan & Khanigaun & Mujhung & Siluwa & All Areas \\
\hline Human labor (man-days/ha) & 164 & 215 & 245 & 442 & 266 \\
Own & 119 & 191 & 217 & 372 & 225 \\
& & & & & $(83.44)$ \\
Hired & 45 & 24 & 28 & 70 & 41 \\
$\quad$ t-value & $3.039 * * *$ & $3.992^{* * *}$ & $5.684^{* * *}$ & $8.213^{* * * *}$ & $12.08 * * *$ \\
Land preparation cost (Rs/ha) & 8870 & 9202 & 8628 & 10852 & 9388 \\
$\quad$ Seed (kg/ha) & 2935 & 3219 & 2733 & 2605 & 2873 \\
$\quad$ Own & 1737 & 2992 & 2699 & 2386 & $2454(85)$ \\
Purchased & 1198 & 227 & 34 & 219 & 419 \\
Organic manures (kg/ha) & 16373 & 26392 & 23680 & 38657 & 26275 \\
Own & 16258 & 26215 & 23384 & 38657 & 26129 \\
& & & & & $(99)$ \\
Purchased & 121 & 177 & 296 & 0 & 148 \\
Organic insecticides (NRs/ha & 210 & 0 & 0 & 0 & 52. \\
\hline
\end{tabular}

Figures in the Parentheses indicate the percentage

*** indicates the values at 0.01 level of significance

\section{Cost of production}

The cost of production included different variable cost items like land preparation, human labor, seed, manure, pesticides, interest on operating cost and rental value of land. Both cash expenditure and imputed value of family supplied inputs were included in the analysis and shown in table 4.

It was found from the study that the highest cost was incurred for seed (rhizome) (65.1\%). But in the study by USAID (2011), GOK (2011) and Ewuziem \& Onyenobi (2012) reported up to $46 \%, 30.38 \%$ and $25 \%$ cost for seed respectively. The percentage of cost share observed on human labor and organic manure was $15.3 \%$ and $10.5 \%$ respectively in the study area. Mulching cost was included in the labor as it is collected from own land or from nearby forest free of cost.

Cost for human labor was higher in Siluwa 1.5 times the cost of other remaining areas. It was due to higher labor use for organic manure application. The use of organic manure in Siluwa was almost double to other three areas. Seed cost was observed less in Siluwa; it was mostly due to excess use of local seed at lower price. The average cost of production for cash cost basis in Bhairabsthan was higher (NRs/ha 83195) among four sites. 
Table 4. Cost of ginger cultivation by the sample farmers in the study areas

\begin{tabular}{|c|c|c|c|c|c|}
\hline \multirow{2}{*}{ Cost items } & \multicolumn{5}{|c|}{ (Nepalese Rupees/ha) } \\
\hline & Bhairabsthan & Khanigaun & Mujhung & Siluwa & All area \\
\hline Land preparation: & 8870 & 9202 & 8628 & 10852 & $9388(5.2)$ \\
\hline Own & 4374 & 3288 & 4488 & 6931 & 4770 \\
\hline Hired & 4496 & 5914 & 4140 & 3921 & 4618 \\
\hline Human labor: & 24275 & 22565 & 24563 & 39664 & $27767(15.3)$ \\
\hline Own & 16193 & 18924 & 19966 & 33720 & 22201 \\
\hline Hired & 8082 & 3641 & 4597 & 5944 & 5566 \\
\hline Seed & 139021 & 122035 & 136834 & 76200 & $118523(65.1)$ \\
\hline Own & 74731 & 107963 & 122315 & 71802 & 94203 \\
\hline Purchased & 64291 & 14072 & 14519 & 4398 & 24320 \\
\hline Organic manures: & 13248 & 16007 & 14208 & 33184 & $19162(10.5)$ \\
\hline Own & 12936 & 15632 & 13989 & 33184 & 18935 \\
\hline Purchased & 312 & 375 & 219 & 0 & 226 \\
\hline Organic Insecticides & 210 & 0 & 0 & 0 & $52(0.0)$ \\
\hline $\begin{array}{l}\text { Interest on hired and } \\
\text { purchased operating } \\
\text { capital (10-12\% for } \\
9-12 \text { months) }\end{array}$ & 5804 & 2880 & 1761 & 1070 & $2879(1.6)$ \\
\hline Land use cost & 5357 & 3958 & 3853 & 3479 & $4162(2.3)$ \\
\hline Total cost: & & & & & \\
\hline Cash cost basis & 83195 & 26882 & 25235 & 15333 & 37661 \\
\hline Full cost basis & 196786 & 176648 & 189846 & 164449 & 181933(100) \\
\hline
\end{tabular}

Note: Conversion rate: $1 \mathrm{USD}=78.0 \mathrm{NR}$, Figures in the parentheses are percentages of total cost.

\section{Profitability}

Table 5 shows that farmers received on an average $11378 \mathrm{~kg} / \mathrm{ha}$ of total yield. Main yield was found higher in Khanigaun. This VDC is famous for ginger seed production in Palpa as well as in western region of Nepal. In the four study sites only two sites have practices of collecting mother rhizome. Among them Bhairabsthan has higher practices of collecting the rhizome. The average gross return from ginger production was found NRs/ha 198518 (USD 2545.1).

Gross margin on full cost basis was the highest in Bhairabsthan (NRs/ha 33880) while on cash cost basis the highest gross margin was found in Mujhung (NRs/ha 176668). Average gross margin on full cost basis was NRs/ha 16585 (USD 212.56). But in cash cost basis the average gross margin was 160857 (USD 2062.27). 
Table 5. Profitability of ginger cultivation in the study areas

\begin{tabular}{lcc|c|c|c}
\hline Items & Bhairabsthan & Khanigaun & Mujhung & Siluwa & $\begin{array}{c}\text { All } \\
\text { Areas }\end{array}$ \\
\hline Main yield (kg/ha) & 9940 & 11848 & 11642 & 9635 & 10766 \\
Yield of mother rhizome (kg/ha) & 1644 & 0 & 804 & 0 & 612 \\
Total yield (kg/ha) & 11584 & 11848 & 12446 & 9635 & 11378 \\
Gross return (NRs/ha) & 230666 & 195796 & 201903 & 165708 & 198518 \\
Total cost (NRs./ha) & & & & & \\
Cash cost basis & 83195 & 26882 & 25235 & 15333 & 37661 \\
Full cost basis & 196786 & 176648 & 189846 & 164449 & 181933 \\
Gross margin (NRs/ha) & & & & & \\
Cash cost basis & 147471 & 168914 & 176668 & 150375 & 160857 \\
Full cost basis & 33880 & 19148 & 12057 & 1259 & 16585 \\
Benefit cost ratio (BCR) & & & & & \\
Cash cost basis & 2.77 & 7.28 & 8.00 & 10.81 & 7.22 \\
Full cost basis & 1.17 & 1.11 & 1.06 & 1.01 & 1.09 \\
Cost of ginger (NRs/ha) & & & & & \\
Cash cost basis & 7.18 & 2.27 & 2.03 & 1.59 & 3.27 \\
Full cost basis & 16.99 & 14.91 & 15.25 & 17.07 & 16.05 \\
Return from ginger(NRs./kg) & 19.91 & 16.53 & 16.22 & 17.20 & 17.46 \\
\hline Source: Fin & & & & &
\end{tabular}

Source: Field survey, 2012

The average benefit cost ratio was 7.22 and 1.09 on cash cost basis and full cost basis, respectively. The Lowest benefit cost ratio on cash cost basis in Bhairabsthan was due to high charges for labor and other external inputs. From this study, it can be said that commercial and access areas are cost effective on cash cost basis compared to remote and semi-commercial farming areas. The average cost of ginger was NRs. 3.27 on cash cost basis and NRs.16.05 on full cost basis.

\section{Factors affecting ginger production}

The maximum likelihood estimates for parameter of the Cobb Douglas production function of ginger is presented in Table 6 . Among the five parameters three were statistically significant and positive. The empirical results indicated that the co-efficient of seed cost and labor cost were positive and significant at $1 \%$ level. But years of crop rotation was found positive and significant at 5 percent level. 
Table 6. Maximum likelihood estimates of Cobb-Douglas production function.

\begin{tabular}{c|c|c|c|c|c}
\hline & \multicolumn{2}{|c|}{ Unstandardized Coefficients } & Standardized Coefficients & \multirow{2}{*}{ T Value } & Sig. Level \\
\cline { 2 - 4 } & $\mathrm{B}$ & Std. Error & Beta & & \\
\hline (Constant) & -0.344 & 0.429 & & -0.802 & 0.424 \\
In Seedc & 0.589 & 0.063 & 0.554 & 9.288 & $0.000^{* * *}$ \\
lnManurec & -0.049 & 0.090 & -0.033 & -0.540 & 0.589 \\
ln Labc & 0.568 & 0.111 & 0.347 & 5.108 & $0.000^{* * * *}$ \\
lnCropr & 0.190 & 0.092 & 0.074 & 2.059 & $0.041^{* *}$ \\
InFamilyz & 0.112 & 0.116 & 0.035 & 0.966 & 0.335 \\
\hline
\end{tabular}

a. Dependent Variable: $\ln Y g, \mathrm{R}^{2}=0.715$,

$* * *$ and $* *$ indicate the significant at $1 \%$ and $5 \%$ level of probability respectively

The regression coefficient for seed cost was 0.554 , which depicted that with 100 $\%$ increase in cost on seed production could be increased by $55.4 \%$. Similarly with the increase in labor cost by $100 \%$ increase in production could be increased by $34.7 \%$ as the coefficient is 0.347 . Number of years on crop rotation if increased by $100 \%$ the production is increased by $7.4 \%$. Thus total output (revenue) is more responsive to ginger seed, labor and years of crop rotation. Similar type of result was also found by Thakur \& Gautam (2005) and Poudel et al. (2010).

Cobb Douglas production function also indicates the elasticity of production. The sum of the coefficients (output elasticity) of the variables of Cobb-Douglas production function is 0.977 . The value is near to unity; suggest farming need judicious use of such inputs.

\section{Constraints}

Although ginger was observed as more profitable crop only at own input use condition, there are several constraints to its higher production. Producers are facing several production related problems like input supply, technical knowhow, pest management and infrastructure development. In the study areas, 35 percent farmers responded that they are facing problem of unavailability of quality planting materials. The next most felt problem was the pest management. Some respondents reported that their crop was destroyed by the diseases like rhizome rot and leaf spot in the field as well as in stored condition. The third prioritized problem was the lack of technical knowledge and skills for ginger production (Table 7). 
Table 7. Problems of ginger cultivation in the study areas

\begin{tabular}{l|llllllll}
\hline Problems & Bhairabsthan & Khanigaun & Mujhung & Siluwa & All areas & Rank \\
\hline $\begin{array}{l}\text { Insufficient supply } \\
\text { of manure and } \\
\text { mulch }\end{array}$ & $6(10)$ & $9(11.7)$ & $6(10)$ & $3(5)$ & $24(10.0)$ & V \\
$\begin{array}{l}\text { Lack of quality } \\
\text { planting materials }\end{array}$ & $34(56.7)$ & $13(21.7)$ & $13(21.7)$ & $24(40)$ & $84(35.0)$ & I \\
$\begin{array}{l}\text { Poor rural } \\
\text { infrastructure }\end{array}$ & $2(3.3)$ & $6(10)$ & $4(6.7)$ & $\begin{array}{l}14 \\
(23.3)\end{array}$ & $26(10.8)$ & IV \\
$\begin{array}{l}\text { Lack of technical } \\
\text { knowledge and skills }\end{array}$ & $8(13.3$ & $13(21.7)$ & $7(11.7)$ & $8(13.3)$ & $36(15.0)$ & III \\
$\begin{array}{l}\text { Problem of pest } \\
\text { management }\end{array}$ & $10(16.7)$ & $19(31.7)$ & $30(50)$ & $\begin{array}{l}11 \\
(18.3)\end{array}$ & $70(29.2)$ & II \\
\hline
\end{tabular}

Source: Field Survey, 2012; Figures in parentheses indicate the percentage. ( $\mathrm{N}=240)$ Multiple responses.

\section{Summary and Conclusions}

Based on the study it can be concluded that the growth rate of ginger area and production is in increasing trend. Farmers are using more own resources on ginger farming compared to hired. Ginger cultivation is highly profitable on cash cost basis (BCR=7.22). Seed cost is the major share incurred (65.1 percent) on total cost of production. Gross margin on cash cost basis is higher. The estimated coefficient of factors of production indicated that seed, labor and number of years for crop rotation has significant positive effects in selected locations of Palpa Nepal. Farmer perceived that quality seed, pest management and technical knowledge are major three bottlenecks for ginger production. Thus the study concluded that cost and quality of seed is the major hindrance for ginger farming in study areas.

\section{Recommendations}

$>$ Government intervention is needed to decrease the cost on seed. And seed production system can be strengthened through the establishment of seed capital fund.

- Ginger farming is highly profitable business if input use is made efficient.

$>$ Farmers are encouraged to increase the number of years on crop rotation.

$>$ Ginger farmers should be helped on source seed production and distribution, plant protection and capacity development training.

\section{References}

APROSC \& JIMA. 19195. Nepal Agriculture Prospective Plan (APP). Summary Documents: APROSC, Kathmandu, Nepal. 
Ewuziem, J.E. and V.O. Onyenobi. 2012. Cost and return analysis of ginger production in the Guinea Savannah of Nigeria. Journal of Agriculture \& Food Sciences. 10(2):2636

FAO. 2015. Food and Agriculture Organization of the United Nations, Statistics Division. Retrieved from http://faostat3.fao.org/home/E in 2015/6/14.

GOK. 2011. Report on cost of cultivation of important crops in Kerala 2010-11. Government of Kerala. Department of Economics \& Statistics. Thiruvananthapuram. http://www.ecostat.kerala.gov.in/docs/pdf/reports/cost_culti/cost1011.pdf (Retrieved in $24 / 5 / 2014)$

Lyocks, S.W. J., J. Tanimu and L.Z. Dauji. 2013. Growth and yield parameters of ginger as influenced by varying populations of maize intercrop. Journal of Agricultural and Crop Research. 1(2): 24.

MOAD. 2014. Statistical information on Nepalese agriculture 2013/14. Ministry of Agricultural Development. Singhadarbar, Kathmandu, Nepal.

Monnaf, M.A., M.A. Rahim, M.M.A. Hossain and M.S. Alam. 2010. Effect of planting method and rhizome size on the growth and yield of ginger. Journal of agroforestry and environment. Bangladesh Agricultural University, Mymensingh-2202.4 (2): 73

Poudel, R.R., K.B, Adhikari, P.P. Regmi and D.B. Gurung. 2010. Factors contributing to total revenue: A case study of community based maize seed production program in Chitwan, Nepal. In: Nepalese Journal of Agricultural Sciences. Vol. 8. 72p.

Poudel, R.R., P.P. Regmi, R.B, Thapa, Y.D. GC and D.B. KC. 2015. Socio economic aspects of ginger producers in the western hills of Nepal. Nepalese Journal of Agricultural Sciences. Vol. 13. 48p.

Rahman, H., R. Karuppaiyan, K. Kishor, and R. Denzognpa. 2009. Traditional practices of ginger cultivation in Northeast India. Indian Journal of Traditional Knowledge. 8(1): $23-28$

Thakur, N.S. and J.C. Gautam. 2005. Factor contributing to enhanced productivity of improved maize technology in rain fed hill areas of Nepal: A case study of Deurali agro-ecological research site in Palpa District. In: Proceedings of the Ninth Asian Regional Maize Workshop held September, 5-9, 2005, Beijing, China, CAAS and CIMMYT. 35 p.

USAID. 2011. Value chain/market analysis of the ginger sub-sector. Nepal economic agriculture and trade activity-USAID. General development office, Kathmandu, Nepal. 8 p. 
